\title{
Prevalence of Antiphospholipid Antibodies in HIV-Infected Children in Ile-Ife, South-Western Nigeria

\author{
Oyelese $A T^{1}$, Salawu $L^{2}$, Adejuyigbe $E A^{3}$ and Olasanmi $O^{4}$
}

${ }^{1}$ Department of Haematology and Immunology, Babcock University Teaching Hospital, Ilishan-Remo, Ogun State, Nigeria ${ }^{2}$ Department of Haematology and Immunology, Obafemi Awolowo University Teaching Hospital, Ile-Ife, Osun State, Nigeria

${ }^{3}$ Department of Paediatrics, Obafemi Awolowo University Teaching Hospital, Ile-Ife, Osun State, Nigeria

${ }^{4}$ Department of Community Health, Obafemi Awolowo University Teaching Hospital, Ile-Ife, Osun State, Nigeria

*Corresponding author: Oyelese Adesola T, Department of Haematology and Immunology, Babcock University Teaching Hospital, Ilishan-Remo, Ogun State, Nigeria, Tel: +234-0806-0013-570

\begin{abstract}
Background: Lupus anticoagulant (LA) and anticardiolipin antibodies $(\mathrm{aCL})$ are acquired autoantibodies referred to as antiphospholipid antibodies (aPL). They can be found in infective and non-infective conditions. Infection with the Human immunodeficiency virus (HIV) can predispose patients to having these antibodies and this has been documented in Nigerian adult patients but not in the pediatric age group. To determine the prevalence of antiphospholipid antibodies in HIV-infected children and its association with the clinical stage of infection and possible hematological derangements were the aim of this study.

Methods: One hundred and sixteen HIV-infected children attending the Pediatric Virology Clinic of a tertiary hospital and 61 healthy children age and sex-matched controls were consecutively selected. Ethical approval and informed consent were obtained from the institution and parents/care-givers respectively. Full blood count, direct Coombs' test (DCT), activated partial thromboplastin time, Kaolin clotting time test and anticardiolipin antibody assay were done to screen for antiphospholipid antibodies.

Results: Thirteen (11.2\%) of the subjects and 6 (9.8\%) of the controls were positive for antiphospholipid antibodies ( $\mathrm{aCL}$ and $\mathrm{LA}$ ). Using aCL as a determinant of aPL, $11(9.48 \%)$ and $6(9.84 \%)$ of the subjects and controls respectively had aPL while with LA as the determinant of aPL $7(6.03 \%)$ of the subjects and $4(6.56 \%)$ of the controls had aPL. Eleven (84.6\%) of the subjects positive for aPL had been on highly-active antiretroviral therapy (HAART) for more than 6 months. The effect of antiphospholipid antibodies on PCV, platelet and white cell counts were not significant ( $p$-values; 0.41 , 0.82 and 0.66 ). None had any clinical feature associated with the presence of aPL and DCT was negative in all who had antiphospholipid antibodies.

Conclusion: Antiphospholipid antibodies are higher in children than in adults. The presence of these antibodies not influenced by infection or non-infection with the HIV virus though the infected had higher prevalence rate. Symptoms and signs of antiphospholipid syndrome were absent.
\end{abstract}

\section{Keywords}

Human immunodeficiency virus, Anticardiolipin antibodies, Lupus anticoagulant, Kaolin clotting time

\begin{abstract}
Abbreviations
AIDS: Acquired Immunodeficiency Syndrome; aCL: Anticardiolipin Antibodies; aPL: Antiphospholipid Antibodies; APS: Antiphospholipid Syndrome; aPTT: Activated Partial Thromboplastin Time; DCT: Direct Coombs Test; HAART: Highly-Active Antiretroviral; LA: Lupus Anticoagulant; OI: Opportunistic Infection; PCV: Packed Cell Volume; PT: Prothrombin Time; WBC: White Blood Cell
\end{abstract}

\section{Introduction}

Immunological pertubations are observed phenomena in HIV infection both in children and adults. This combination of autoimmunity and immune dysfunction in patients infected with HIV is an interesting observation [1]. Antiphospholipid antibodies (aPL) are a heterogeneous group of acquired autoantibodies. These could be immunoglobulin $\mathrm{G}, \mathrm{M}, \mathrm{A}$ or a combination of these subtypes. Different combinations of phospholipids, phospholipid-binding proteins or both are recognized by these autoantibodies and they have also been reported in various clinical settings [2].

The three major subtypes that have been described and can be detected by immunoassay and functional coagulation assays are Lupus anticoagulant (LA), anticardiolipin antibodies (aCL) and anti-beta 2 glycoprotein antibodies (anti-ß2GPI) [3].

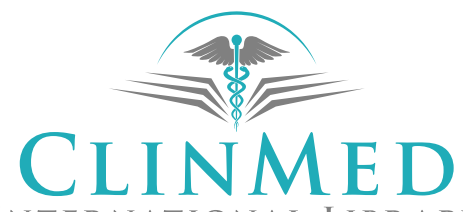

INTERNATIONAL LIBRARY

Citation: Oyelese AT, Salawu L, Adejuyigbe, Olasanmi O (2019) Prevalence of Antiphospholipid Antibodies in HIV-Infected Children in Ile-Ife, South-Western Nigeria. Int J Blood Res Disord 6:045. doi. org/10.23937/2469-5696/1410045

Accepted: December 10, 2019: Published: December 12, 2019

Copyright: (C) 2019 Oyelese AT, et al. This is an open-access article distributed under the terms of the Creative Commons Attribution License, which permits unrestricted use, distribution, and reproduction in any medium, provided the original author and source are credited. 
The clinical significance of antiphospholipid antibodies is derived from their association with a syndrome of venous and or arterial thrombosis, recurrent fetal loss and immune thrombocytopaenia referred to as Antiphospholipid syndrome (APS) though not all those who have these antibodies develop the syndrome. Other manifestations include stroke, pulmonary embolism and autoimmune haemolytic anaemia [2].

Lupus anticoagulant and anticardiolipin antibodies have been detected in patients with HIV infection [4-6]. Both types of anticardiolipin antibodies (the pathogenic or $\beta_{2}$ GPI-dependent) as well as the non-pathogenic (non- $\beta_{2}$ GPI-dependent) antibodies may be detected and there is diversity not only of the isotypes but also of the aPL. There is also a low prevalence of antibodies directed toward $\beta_{2}$ GPI in HIV-infected patients thus making APS and its manifestation uncommon in HIV infection [1].

Antiphospholipid antibodies in the pediatric age group bear some uniqueness; in that their presence is more infection-related and clinical manifestations are more severe when present [7-9]. Moreover, antibodies found in this setting do not show anti- $\beta_{2}$ GPI activity and in general not associated with thrombotic events [10].

The mechanism possibly involved in the autoimmune manifestations in HIV infection include the direct effect of HIV on endothelial, synovial and other haemopoietic cells resulting in destruction of CD4+ T-cells, increased cytotoxic cell activity and increased expression of autoantigens. Molecular mimicry is one the proposed mechanisms in the development of autoimmune disease secondary to an infection $[1,11]$.

The pathogenesis of antiphospholipid antibodies in HIV-infected patients is unknown but it has been suggested that it could be due to the stimulation of $B$ cells in response to opportunistic infections or HIV itself, resulting in the production of polyclonal immunoglobulins in a non-specific manner [12]. It could also represent the biological expression of a hyper-reactive immune system, particularly following the commencement of highly-active antiretroviral therapy (HAART) in the HIV-infected [13].

\section{Materials and Methods}

\section{Patients sampling and study design}

A prospective case-control study was conducted among 116 consecutively selected HIV-infected children on HAART or HAART-naive attending the Pediatric unit of the Virology Research Clinic, Obafemi Awolowo University Teaching Hospitals Complex, Ile-Ife. Sixty-one healthy HIV-negative children recruited from the community served as controls. The children that served as the control group were apparently healthy children recruited from the communi- ty; particularly, from places of worship. Subjects and controls were aged 18 months to 14 years. Biodata was collected with the use of a proforma. This was carried out between May 2013 and June 2014. Ethical approval and informed consent were obtained from the institution's research and ethical committee and parents/care-givers respectively.

\section{Materials and methods}

Six milliliters of venous blood was aseptically collected from each of the 116 HIV-infected children and the 61 HIV-negative controls.

\section{Full blood count and CD4+ T-Lymphocyte count}

One millilitre of venous blood was collected into pediatric-sized vacuum potassium ethylenediaminetetraacetic acid ( $K_{2}$ EDTA) bottle and mixed well for the assessment of Full blood count and $\mathrm{CD} 4+$ cell count.

Full blood count was carried out using the Sysmex $\mathrm{KX}-21 \mathrm{~N}$ machine while the CD4+ lymphocyte count was done using the CyFlow Counter 1 machine following both reagent and machine instructions. $2.75 \mathrm{mls}$ was collected into a plain bottle for the direct Coombs' test and anticardiolipin antibody (aCL) assay.

A 1 in 9 dilution of venous blood was prepared by mixing $0.25 \mathrm{ml}$ of $32 \mathrm{~g} / \mathrm{l}$ Trisodium citrate with $2.25 \mathrm{ml}$ of blood for the assessment of aPTT and KCT. These samples were centrifuged at 4000 revolution per minute for 15 minutes within 2-4 hours of collection to obtain platelet poor plasma which were stored at $-80^{\circ} \mathrm{C}$ pending analysis. Activated partial thromboplastin time (aPTT) was carried out by using LA-sensitive aPTT reagent (Aniara Diagnostica, USA). Subjects and controls with persistently elevated aPTT values following mixing test were further assayed for antiphospholipid antibodies namely, Lupus anticoagulant and anticardiolipin antibodies (isotypes $\lg G$ and $M$ ).

\section{Lupus anticoagulant}

Lupus anticoagulant was detected using the Kaolin clotting time test in accordance with the recommendations of the Subcommittee on lupus anticoagulant/ antiphospholipid antibody of the Scientific and Standardization Committee of the International Society on Thrombosis and Haemostasis.

\section{Anticardiolipin antibody}

Anticardiolipin antibody assay was carried out using the ELISA method (Diagnostic Automation Inc/Cortex Diagnostics, USA).

\section{HIV status determination}

HIV screening/confirmation was done using both the Determine and Unigold strips according to the serial rapid test algorithm [14].

\section{Direct coombs test}


Table 1: Demographic characteristics and laboratory parameters (mean \pm SD) of subjects and controls.

\begin{tabular}{|c|c|c|c|}
\hline Parameters & Subjects $(n=116)$ & Controls $(n=61)$ & $p$ value \\
\hline Gender & $\begin{array}{l}\text { Male }=63(54.3 \%) \\
\text { Female }=53(45.7 \%)\end{array}$ & $\begin{array}{l}\text { Male }=26(42.6 \%) \\
\text { Female }=35(57.4 \%)\end{array}$ & 0.0001 \\
\hline $\begin{array}{l}\text { Age (years) } \\
\text { CD4+ (cells/ } \mu l)\end{array}$ & $\begin{array}{l}7.2 \pm 3.3(\text { median }=7) \\
878 \pm 541\end{array}$ & $\begin{array}{l}8.8 \pm 3.1(\text { median }=9) \\
1,178 \pm 327\end{array}$ & 0.0002 \\
\hline PCV (\%) & $33.6 \pm 3.7$ & $37.5 \pm 3.5$ & $<0.0001$ \\
\hline WBC $\left(\times 10^{9} / L\right)$ & $5.6 \pm 2.9$ & $4.9 \pm 3.2$ & 0.2 \\
\hline Platelet Count $\left(\times 10^{9} / \mathrm{L}\right)$ & $268 \pm 104$ & $219 \pm 79$ & 0.002 \\
\hline APTT (sec) & $39.4 \pm 4.2$ & $40.1 \pm 4.0$ & 0.3 \\
\hline
\end{tabular}

Legends: CD4+: CD4+ lymphocyte count; PCV: Packed cell volume; WBC: White blood cell count; PLT: Platelet count; APTT: Activated partial thromboplastin time.

Table 2: Haematological profile of subjects and controls positive for antiphospholipid antibodies.

\begin{tabular}{|c|c|c|c|c|}
\hline Parameters & Subjects $(n=13)$ & Controls $(n=6)$ & t value & p value \\
\hline PCV (\%) & $32.9 \pm 3.2$ & $37.3 \pm 3.3$ & 3.3 & 0.004 \\
\hline WBC (109/L) & $5.7 \pm 2.5$ & $4.1 \pm 713$ & -2.1 & 0.05 \\
\hline PLT (10/L) & $302 \pm 109$ & $235 \pm 119$ & -1.3 & 0.1 \\
\hline CD4+ (cells/ $\mu \mathrm{l})$ & $964 \pm 817$ & $1,200 \pm 284$ & 1.2 & 0.2 \\
\hline APTT (sec) & $43.4 \pm 5.7$ & $45.6 \pm 5.3$ & 0.86 & 0.39 \\
\hline
\end{tabular}

Legends: PCV: Packed cell volume; PLT: Platelet count; CD4+: CD4+ lymphocyte count; APTT: Activated partial thromboplastin time.

The Direct Coombs' test (DCT) was performed as described by Laffan et al. in Dacie and Lewis Practical Haematology, $10^{\text {th }}$ Edition.

\section{Statistical analysis}

SPSS version 16 was used to analyse data collected through a proforma. Percentages were used to describe frequency analysis of categorical variables. Numerical variables were summarized as means and standard deviations where appropriate. Pearson's chi-square was used to determine associations between categorical variables. Means of numerical variables were compared with categorical variables using 2 -sample independent t-test. A p-value of $<0.05$ defined the level of statistical significance.

\section{Results}

A total of 116 HIV-infected children (subjects) and 61 HIV-negative controls were investigated. Subjects were aged between 18 months and 14 years with a mean age of $7.2 \pm 3.3$ years. Controls were of similar ages and their mean age was $8.7 \pm 3.3$ years. Male and female subjects were $63(54.3 \%)$ and $53(45.7 \%)$ respectively while controls were made up of 26 (42.6\%) males and 35 (57.4\%) females. One hundred and four (89.7\%) of the subjects were on HAART and $12(10.3 \%)$ were HAART-naïve (Table 1 ).

\section{Full blood count and CD4+ T-Lymphocyte count}

The mean values of the packed cell volume (PCV), platelet and CD4+ lymphocyte count of the subjects were $33.6 \pm 3.7 \%, 268 \pm 104 \times 10^{9} / \mathrm{L}$ and $878 \pm 541$ cells/ $\mu \mathrm{l}$ respectively while those of the controls were $37.5 \pm$ $3.5 \%, 219 \pm 79 \times 10^{9} / \mathrm{L}$ and $1,178 \pm 327$ cells $/ \mu \mathrm{l}$. When these values were compared, the differences were statistically significant (PCV: $p<0.0001$; platelet count: $p=$ 0.002; CD4+: $p=0002$ ). However, the WBC count and the aPTT were not statistically significant (WBC: $p=0.2$; aPTT: $p=0.3$ ) (Table 2).

\section{Antiphospholipid antibodies}

Thirteen (11.2\%) of the 116 subjects were positive for aPLs. Using aCL as a determinant of aPL, only 11 $(9.48 \%)$ of the 116 subjects had antiphospholipid antibodies. When lupus anticoagulant as determined by KCT was used as a determinant of aPL, only 7 (6.03\%) of these subjects had aPL. Of the 13 subjects with aPL, 8 were males (i.e 8 of 63 males were aPL-positive) and 5 were females (i.e 5 of 53 females were aPL positive). The difference using the Pearson's chi square was not statistically significant $\left(\chi^{2}=0.321, p=0.57\right)$.

Six (9.8\%) of the controls were positive for aPLs. Similarly, many of the positive results were by aCL compared to LA (9.8\% vs. $6.6 \%)$. There were 3 of the 35 females and also 3 of the 26 males that were positive for aPLs. This was not statistically significant $\left(\chi^{2}=0.15, p\right.$ $=0.7)$. IgG and IgM isotypes of anticardiolipin antibody were assayed. Eleven of the subjects were positive for both isotypes and six of the controls showed positivity for both aCL IgG and IgM (Table 3).

The effect of antiphospholipid antibodies on PCV, 
platelet and white cell counts were not significant ( $\mathrm{Ta}$ ble 4).

Eleven (84.6\%) of the subjects positive for antiphospholipid antibodies had been on HAART for more than 6 months. Nine were in World Health Organization (WHO) clinical stage 1 and two were in stages 2 and 3 . None of the subjects presented with any feature associated with the presence of aPLs and DCT was negative in all of them.

Comparing prevalence of aPLs in HAART-naïve patients ( 2 of 12 ) and patients on ARV treatment (11 of $104)$, there was no association established $\left(\chi^{2}=0.4, p\right.$ $=0.52$ ). Furthermore, HIV infection did not influence the development of antiphospholipid antibodies as we document 13 of 116 infected to have aPL and 6 of 61 HIV-negative patients to have aPL $\left(\chi^{2}=0.49, p=0.78\right)$.

Table 3: Subjects and controls with positivity for $\mathrm{aCL}$ and titres of $\lg G$ and $\lg M$.

\begin{tabular}{|l|l|l|}
\hline Subjects & Ig G & Ig M \\
\hline 6 & High Positive & High Positive \\
\hline 7 & Low Positive & Low Positive \\
\hline 13 & Low Positive & Low Positive \\
\hline 17 & Low Positive & Moderate Positive \\
\hline 18 & Low Positive & Low Positive \\
\hline 19 & Low Positive & Negative \\
\hline 27 & Moderate Positive & Low Positive \\
\hline 80 & Low Positive & Low Positive \\
\hline 104 & Low Positive & Negative \\
\hline 113 & Negative & Low Positive \\
\hline 117 & Low Positive & Low Positive \\
\hline & & \\
\hline Controls & Ig G & Ig M \\
\hline C6 & Low Positive & Low Positive \\
\hline C15 & Low Positive & Low Positive \\
\hline C35 & Negative & Low Positive \\
\hline C43 & Negative & Low Positive \\
\hline C53 & Negative & Moderate Positive \\
\hline C58 & Low Positive & Moderate Positive \\
\hline
\end{tabular}

Legends: Ig: Immunoglobulin; aCL: Anticardiolipin antibody.

\section{Discussion}

Infection and autoimmune disorders have been implicated in the development of antiphospholipid antibodies in children. Viral infections are the commonest triggers but others could be bacterial, parasitic and spirochaetal. Antiphospholipid antibodies triggered by infections have been described as being transient and non-pathogenic [15].

Concerning the prevalence of aPLs in HIV-infected children, the literature is sparse, most reports being incidental findings and case reports [16].

A higher prevalence rate of lupus anticoagulant was observed in this study compared to similar studies amongst adult HIV-infected patients $[4,5]$. This could be due to the methods used in this study. The use of two various methods increases the sensitivity and specificity of results.

The only study done among children in Nigeria was by Olayemi, et al. in sickle cell disease patients who found a prevalence of $1.8 \%$ for LA [17]. Although sickle cell disease is also considered an immunosuppressive disorder, the degree of immunosuppression is not comparable to that obtained in HIV infection; in which patients are susceptible to bacterial, viral, fungal and parasitic infections that may trigger the formation of antiphospholipid antibodies.

Of the two subtypes of antiphospholipid antibodies ( $L A$ and $\mathrm{aCL}$ ) tested for in this study, anticardiolipin antibodies (aCL) were found to be more prevalent than lupus anticoagulant.

9.8\% of the HIV-negative controls were also positive for aPLs; supporting the fact that there are other triggers for the presence of these antibodies in children apart from HIV infection [18]. Anticardiolipin antibodies among healthy children have been reported to be between $2 \%$ and $82 \%$ [19-21]. Frequent infections by varying etiological agents characterize childhood, hence putting the immune system under immense pressure and in effect making children produce more antiphospholipid antibodies than adults.

The IgG isotype was higher in the subjects in this

Table 4: Comparison of the effect of antiphospholipid antibody positivity and negativity on haematological variables.

\section{Subjects}

PCV (\%)

Mean \pm SD

SD $\quad 327 \pm 4.1$

WBC $(\times 10 \% / L) \quad 5,845 \pm 2,541$

\begin{tabular}{l|l} 
PLT $(\times 10 \% / L)$ & $\begin{array}{l}280,333 \pm \\
85,970\end{array}$
\end{tabular}

CD4 (/ul) $812 \pm 557$

APTT (secs) $46.6 \pm 3.9$

\section{aPL POS}

aPL NEG

$33.7 \pm 3.6$

$5,635 \pm 3,026$

$265,913 \pm$

107423

$885 \pm 542$

$38.4 \pm 3.2$

\section{Controls}

\begin{tabular}{|l|l|l|l|l|l|l|}
\hline t-test & p-value & & aPL POS & aPL NEG & t-test & p-value \\
\hline 0.84 & 0.41 & Mean \pm SD & $37.4 \pm 3.3$ & $37.5 \pm 3.5$ & 0.04 & 0.97 \\
\hline-0.23 & 0.82 & & $4,171 \pm 713$ & $5,099 \pm 3,475$ & 0.69 & 0.49 \\
\hline-0.44 & 0.66 & & $235,000 \pm$ & $216,880 \pm$ & -0.56 & 0.58 \\
\hline 0.43 & 0.67 & & 119,983 & 73,442 & & \\
\hline-8.45 & 0.0000 & & $1,248 \pm 284$ & $1,168 \pm 333$ & -0.61 & 0.55 \\
\hline
\end{tabular}

aPL: Antiphospholipid antibodies; POS: Positive; NEG: Negative; PCV: Packed cell volume; WBC: White cell count; PLT: Platelet; CD4: Cluster of differentiation 4; APTT: Activated partial thromboplastin time. 
study and similar finding was reported by Stimmler, et al. [22] in 26 adult HIV-infected patients in whom a higher mean of IgG aCL was observed. However, these had AIDS and opportunistic infections (Ols) but interestingly, none of the subjects positive for anticardiolipin antibodies in this study had AIDS or Ols.

Anticardiolipin antibodies were similarly found at a higher frequency among controls in this study with $\mathrm{aCL}$ IgM being significantly higher than IgG isotype $(100 \%$ vs. $42.9 \%)$. The finding of a higher aCL positivity among this healthy controls in this study is similar to findings in other studies [19-21]. Studies by Rapizzi, et al. [20] and Galrao, et al. [23] revealed a higher IgG isotype and this may be considered as the epiphenomenon of vaccinations, nutrition and infections in the pediatric population [24].

A study by Ankri, et al. [25] among 90 HIV-infected patients found a lower CD4+ lymphocyte count in patients with antiphospholipid syndrome (APS) compared to those without APS and that gender, risk factors and stage of disease between patients with HIV and IgG aCL and HIV-infected patients without antibody was not significant.

Generally, antibodies induced by infections are transient, of low titre, non-pathogenic and most often of the IgM subtype however, several reports have shown otherwise $[15,26,27]$. Low-positive titres of aPL found in this study agrees with the description of aPL induced by infective organisms and this might explain the absence of any clinical feature related to the presence of aPLs.

Clinical manifestations due to the presence of these antibodies vary among studies and systematic studies are sparse because of the relatively low prevalence of APS and its heterogeneity among children [6]. Known clinical features associated with the presence of these antibodies were not seen in any of those positive for aPL.

A "two-hit" hypothesis has been proposed to explain the presence of high aPL titres and the absence of symptoms. This hypothesis states that endothelial dysfunction is induced by the presence of aPLs representing the first-hit and then the second-hit which may be pregnancy, infection, smoking, hypertension, atherosclerosis, obesity or vascular injury triggers thrombosis $[2,27]$. However, in children most of these are not common risk factors.

The absence of clinical features can also be explained by the concept of developmental haemostasis which states that there are age-dependent differences in the coagulation and fibrinolytic system [28]. Several studies have reported varying findings relating to thrombosis. Hunt, et al. [29] observed that the incidence of thrombosis is lower in children than in the adults because of increased levels of physiologic anticoagulants. A case of thrombosis and recurrent thrombosis in children was reported by Shah, et al. [16] with reduced CD4+ lymphocyte counts $(<200$ cells/ $\mu \mathrm{l})$, presence of opportunistic infections, neoplasms, or autoimmune disorder such as autoimmune haemolytic anaemia as events predisposing to thrombosis.

A strong relationship between the presence of LA and thrombotic events was found by Berube, et al. [30] who observed that having both $\mathrm{LA}$ and $\mathrm{aCL}$ did not strengthen the relationship between patients with thrombotic complications and aPLs. This was also observed in this study as none of those who were positive for both $\mathrm{LA}$ and $\mathrm{aCL}$ presented with or had history suggestive of thrombosis.

The dysfunctional state of the immune system in HIV infection and/ or immature nature of the immune system in children could explain the negative DCT in all subjects and which is similar to the findings of Ndakotsu, et al. in adult patients [4].

\section{Conclusion}

The presence of these antibodies were not influenced by infection or non-infection with the HIV. Sex, clinical stage of disease and HAART does not influence its presence and antiphospholipid syndrome may not be present.

\section{References}

1. Zandman Goddard G, Shoenfeld Y (2002) HIV and autoimmunity. Autoimmun Rev 1: 329-337.

2. Levine JS, Branch DW, Rauch J (2002) The antiphospholipid syndrome. N Engl J Med 346: 752-763.

3. Hanly JG (2003) Antiphospholipid syndrome: An overview. CMAJ 168: 1675-1682.

4. Ndakotsu MA, Salawu L, Durosinmi MA (2009) Lupus anticoagulant in Nigerian patients living with Human Immunodeficiency Virus/Acquired Immunodeficiency Syndrome. J Microbiol Immunol Infect 42: 69-73.

5. Awodu OA, Olayemi EE, Bazuaye GN, Onunu AN (2010) Lupus anticoagulant, in human immunodeficiency virus-infected patients on highly active antiretroviral therapy. Indian J Pathol Microbiol 53: 47-49.

6. Hassoun A, Al-Kaohimi Z, Cervia J (2004) HIV infection and antiphospholipid antibody: Literature review and link to the antiphospholipid syndrome. AIDS Patient Care STDS 18: 333-340.

7. Giordano P, Tesse R, Lassandro G, Fracchiolla D, Ranieri $P$, et al. (2012) Clinical and laboratory characteristics of children positive for antiphospholipid antibodies. Blood Transfus 10: 296-301.

8. Nalli C, Piantoni S, Andreoli L, Motta M, Tincani A (2012) Antiphospholipid syndrome and antiphospholipid antibodies in children: The two sides of the coin. Isr Med Assoc J 14: 310-312.

9. Wincup C, Yiannis I (2018) The differences between childhood and adult onset antiphospholipid syndrome. Front pediatr 6: 362.

10. Galli M, Comfurius P, Barbui T, Zwaal RFA, Bevers EM 
(1992) Anticoagulant activity of $\beta 2$ - glycoprotein 1 is potentiated by a distinct subgroup of anticardiolipin antibodies. Thromb Haemost 68: 297-300.

11. Laffan M, Manning R (2006) Investigations of haemostasis. In: Dacie and Lewis Practical Haematology. (10 ${ }^{\text {th }}$ edn), Churchill Livingstone, Elsevier, Philadelphia, USA, 379440.

12. Blank M, Krause J, Fridkin M, Keller N, Kopolovic J, et al. (2002) Bacterial induction of autoantibodies to beta 2-glycoprotein-1 accounting for infectious etiology of antiphospholipid syndrome. J Clin Invest 109: 797-804.

13. De Larranaga GF, Forastiero RR, Carreras LO, Alonso BS (1999) Different types of antiphospholipid antibodies in AIDS: A comparison with syphilis and the antiphospholipid syndrome. Thrombo Res 96: 19-25.

14. Federal Ministry of Health (2010) National guidelines for HIV and AIDS treatment and care in adolescents and adults. Abuja, Nigeria.

15. Avcin T, Toplak N (2007) Antiphospholipid antibodies in response to infection. Curr Rheumatol Rep 9: 212-218.

16. Shah I (2012) Recurrent thrombosis in an HIV-1 infected child. Indian J Sex Transm Dis 33: 121-123.

17. Olayemi E, Halim NKD, Durosinmi MA, Awodu OA (2005) Lupus anticoagulant in Nigerian children with homozygous sickle cell disease. Annals of African Medicine 4: 122-126.

18. Berkun Y, Kenet G (2008) Pediatric antiphospholipid syndrome. IMAJ 10: 45-47.

19. Levi M (2003) Measuring activated protein $C$ in plasma to assess its role as a critical modulator of coagulation and inflammation. J Thromb Haemost 1: 643-644.

20. Rapizzi E, Ruffati A, Tonello M, Piccoli A, Calligaro A, et al. (2000) Correction of age of anticardiolipin antibodies cut-off points. J Clin Lab Anal 14: 87-90.
21. Caporali R, Ravelli A, De Gennaro F, Neirotti G, Montecucco C, et al. (1991) Prevalence of anticardiolipin antibodies in juvenile arthritis. Ann Rheum Dis 50: 599-601.

22. Stimmler MM, Quismorio Fp, McGehee QG, Boylen T, Sharma OP (1989) Anticardiolipin antibodies in acquired immunodeficiency syndrome. Arch Intern Med 149: 18331835.

23. Galrao L, Brites C, Atta ML, Atta A, Lima I, et al. (2007) Antiphospholpid antibodies in HIV-positive patients. Clin Rheumatol 26: 1825-1830.

24. Avcin T, Ambrozic A, Kuher H, Kveder T, Rozman B (2001) Anticardiolipin and anti-b2 GPL antibodies in sera of 61 apparently healthy children at regular preventive visits. Rheumatology (Oxford) 40: 565-573.

25. Ankri A, Bonmarchand M, Coutellier A, Herson S, Karmochkine M (1999) Antiphospholipid antibodies are an epiphenomena in HIV infected patients. AIDS 13: 1282-1283.

26. Vaarala O, Palusuo T, Kleemola M, Aho K (1986) Anticardiolipin response in acute infections. Clin Immunol Immunopathol 41: 8-15.

27. Giannakopoulos B, Passam F, Rahgozar S, Krillis SA (2007) Current concepts on the pathogenesis of the antiphospholipid syndrome. Blood 109: 422-430.

28. Shah I, Cudgel P (2006) Antiphospholipid syndrome in a Human Immunodeficiency virus 1-infected child. Pediatr Infect Dis J 25: 185-186.

29. Hunt BJ (2008) Pediatric antiphospholipid antibodies and antiphospholipid syndrome. Semin Thromb Hemost 34: 274-281.

30. Berube C, Mitchell L, Silverman E, David M, Saint Cyr C, et al. (1998) The relationship of antiphospholipid antibodies to thromboembolic events in pediatric patients with systemic lupus erythematosus: $A$ cross sectional study. Pediatr Res 44: 351-356. 